\title{
NMR and Fluorescence Studies of DNA Binding Domain of INI1/hSNF5
}

\author{
Dongju Lee, Sunjin Moon, Jihye Yun, Eunhee Kim, ${ }^{\dagger}$ Chaejoon Cheong, ${ }^{\dagger}$ and Weontae Lee* \\ Department of Biochemistry, College of Life Science and Biotechnology, Yonsei University, Seoul 120-749, Korea \\ *E-mail: wlee@spin.yonsei.ac.kr \\ ${ }^{\dagger}$ Magnetic Resonance Team, Korea Basic Science Institute (KBSI), Ochang, Chungbuk 363-883, Korea \\ Received April 21, 2014, Accepted May 26, 2014
}

\begin{abstract}
INtegrase Interactor 1 protein (INI1/hSNF5) or BRG1-associated factor 47 (BAF47) is a SWI/SNF-related matrix associated actin dependent regulator of chromatin subfamily B member. DNA binding domain of INI1/ hSNF5 is cloned into E.coli expression vectors, pET32a and purified as a monomer using size exclusion chromatography. NMR data show that $\mathrm{INI} 1^{\mathrm{DBD}}$ has folded state with high population of $\alpha$-helices. By fluorescence-quenching experiments, binding affinities between INI $1^{\mathrm{DBD}}$ and two double stranded DNA fragments were determined as 29.9 $\pm 2.6 \mu \mathrm{M}$ (GAL4_1) and 258.7 \pm 5.8 (GAL4_2) $\mu \mathrm{M}$, respectively. Our data revealed that DNA binding domain of INI1/hSNF5 binds to transcriptional DNA sequences, and it could play an important role as a transcriptional regulator.
\end{abstract}

Key Words : INI1/hSNF5, DNA binding domain, NMR, Purification, Fluorescence

\section{Introduction}

Integrase interactor 1 protein (INI1)/BRG-1 associated factor 47 (BAF47) is known as a hSNF5 or SMARCB1 and it is a core subunit of ATP-dependent SWI/SNF chromatin remodeling complexes. ${ }^{1-3}$ Chromatin remodeling complexes promote gene expression, transcriptional repression. ${ }^{4-6}$ INI1/ hSNF5 regulates expression of numerous eukaryotic genes by altering DNA-histone interactions and it is the first host protein identified as an IN-interacting factor by two-hybrid screenings. ${ }^{2}$ In previous studies, INI1/hSNF5 interacts with virus proteins, cellular factors such as human immunodeficiency virus type 1 integrase, ${ }^{7}$ human papillomavirus E1, Kaposi's sarcoma-associated herpesvirus K8, ${ }^{9}$ Epstein-Barr virus nuclear antigen, ${ }^{10-12}$ c-MYC(cheng), ALL1, GADD34 and $\mathrm{p} 53 .^{13-15} \mathrm{INI} 1 / \mathrm{hSNF} 5$ is involved in regulation of cell proliferation and cell cycle by prohibiting activation of E2Fdependent genes through p16ink41-CDK4/cyclin D-Rb pathway. ${ }^{16}$ In addition, INI1/hSNF5 plays a role as a tumor suppressor because mutations of INI1 gene lead to aggressive paediatric atypical teratoid and malignant rhabdoid tumors. $^{17}$

INI1/hSNF5 has functional and conserved regions which are two direct imperfect repeats (repeat 1 and repeat 2) and C-terminal coiled-coiled domain, and a homology region 3 (HR3). ${ }^{18}$ The functional domains of INI1/hSNF5 are not well characterized except for Rpt 1 and Rpt 2 motifs, which interact with proteins such as viral or cellular proteins. ${ }^{18}$ Previous reports show that INI1/hSNF5 interacts with the minor groove of double-stranded DNA and then, conforms positive supercoils in relaxed plasmid DNA. It implies that SWI/SNF complex plays an important role in chromatin remodeling through protein-protein interaction. It has been proposed that INI//hSNF5 could bind DNA at the minor groove while hBRG1 has been reported to possess an AT- hook motif which appears to play a role in DNA binding, although its biological functions of DNA binding domain are still unknown. ${ }^{18,19}$ Here, we performed high-yield protein purification and isotope-labeling of DNA binding domain of INI1/hSNF5 (INI1 ${ }^{\mathrm{DBD}}$ ) to initiate structural study by NMR spectroscopy. Data from fluorescence spectrophotometry supports that INI1 ${ }^{\text {DBD }}$ binds double stranded GAL4 DNA sequences.

\section{Materials and Methods}

Cloning and Over-expression of INI1 ${ }^{\text {DBD }}$. Human INI1/ hSNF5 was amplified to INI1 ${ }^{\mathrm{DBD}}$ fragment by polymerase chain reaction (PCR). XhoI/BamHI (NEB) cut each side of amplified fragment. Mixture was incubated $8 \mathrm{~h}$ in $37^{\circ} \mathrm{C}$ heat block. Sub-cloning into modified expression vector $\mathrm{pET} 32 \mathrm{a}$ (Novagen Inc.) contains an N-terminal hexa-histidine [(His) 6 ] affinity tag, Thioredoxin (TRX), tobacco etch virus (TEV) protease recognition sites, which were transformed into Escherichia coli (E. coli) (Strain BL21 DE3) (Novagen Inc). In order to obtain INI1 ${ }^{\mathrm{DBD}}$, cells were grown on LB broth media at $37^{\circ} \mathrm{C}$ until optical density reached around 0.6 at $600 \mathrm{~nm}$ and then, added $1 \mathrm{mM}$ isopropyl $\beta$-D-thiogalactoside (IPTG) from $1 \mathrm{M}$ solution stock. Cells were incubated for 20 hours at $25^{\circ} \mathrm{C}, 160 \mathrm{rpm}$ shaker incubator and harvested by centrifugation at $6000 \times \mathrm{g}$ for 30 minutes. Cell pellets were stored at $-80{ }^{\circ} \mathrm{C}$ freezer.

Purification of INI1 ${ }^{\text {DBD }}$. Harvested cells were suspended in lysis buffer [ $25 \mathrm{mM}$ Sodium Phosphate, $300 \mathrm{mM} \mathrm{NaCl}, 5$ $\mathrm{mM} \beta$-mercaptoethanol, protease inhibitor cocktail-(Roche) $\mathrm{pH} 7.5$ ] and lysed by sonicator [ $90 \%$ amplify, 1s pulse, 10 cycle]. The cell lysates were centrifuged for 30 minutes, $14000 \times \mathrm{g}$ at $4{ }^{\circ} \mathrm{C}$. After centrifugation, $\mathrm{Ni}^{2+}$ affinity chromatography was used for protein binding (Amersham Pharmacia Biotech, Uppsala, Sweden). The proteins were further wash- 
ed with $60 \mathrm{mM}$ imidazole washing buffer and eluted with $500 \mathrm{mM}$ imidazole elution buffer. TRX-tag was cleaved with Tobacco etch virus (TEV) protease at $25^{\circ} \mathrm{C} .{ }^{20}$ Final purification was performed by size exclusion column chromatography using a HiLoad Superdex 75 column in $10 \mathrm{mM}$ HEPES, $100 \mathrm{mM} \mathrm{NaCl}, 10 \mathrm{mM}$ Dithiothreitol (DTT), $0.01 \% \mathrm{NaN}_{3}$ solution at $\mathrm{pH} 7.0$.

Size exclusion chromatography with four reference proteins [albumin $(66 \mathrm{kDa})$, carbonic anhydrase $(29 \mathrm{kDa})$, cytochrome C (12.4 kDa) and aprotinin $(6.5 \mathrm{kDa})]$ was used to confirm the molecular weight of INI $1^{\mathrm{DBD}}$ by the following equation: $\log \mathrm{Y}=-1.2177 \mathrm{X}+6.263$ (X = elution fraction/ $45.85 \mathrm{~mL}, \mathrm{R} 2=0.9942)$. Purified protein was concentrated to $1.0 \mathrm{mM}$ using an Amicon Ultra centrifugal filter device (Millipore).

NMR Spectroscopy. For hetero-nuclear NMR experiments, we prepared isotope labeled proteins. Cells were cultured in
M9 minimal medium containing ${ }^{15} \mathrm{~N}$ labeled $\mathrm{NH}_{4} \mathrm{Cl}\left({ }^{15} \mathrm{~N}\right.$, 99\%, Cambridge Isotope Laboratories, Inc.). Protein sample was prepared in NMR buffer solution (10 mM HEPES, 100 $\mathrm{mM} \mathrm{NaCl}, 2 \mathrm{mM}$ DTT, $0.01 \% \mathrm{NaN}_{3}$, at $\mathrm{pH} 7.0$ containing $\left.90 \% \mathrm{H}_{2} \mathrm{O} / 10 \% \mathrm{D}_{2} \mathrm{O}\right)$. All NMR experiments were performed at $25{ }^{\circ} \mathrm{C}$ on a Bruker DRX900 spectrometer equipped with a z-shielded gradient triple-resonance cryo-probe. The ${ }^{1} \mathrm{H}$ chemical shifts were referenced to internal sodium 4,4dimethyl-4-silapentane-1-sulfonate (DSS). The ${ }^{1} \mathrm{H}^{-15} \mathrm{~N}$ HSQC experiment was acquired using a uniformly ${ }^{15} \mathrm{~N}$-labeled sample. Pulsed-field gradient (PFG) techniques with a WATERGATE pulse sequence were used for all $\mathrm{H}_{2} \mathrm{O}$ experiments, resulting in a good suppression of the solvent signal. ${ }^{21}$ All NMR data were processed using NMRpipe and NMRDraw software. ${ }^{22}$

Fluorescence Experiments. Two double-stranded oligonucleotides, (GAL4_1 (5'-CGATGATGAAGATACC-3'), GAL4_2 (5'-GTGCACGATGCACAG-3)) were designed

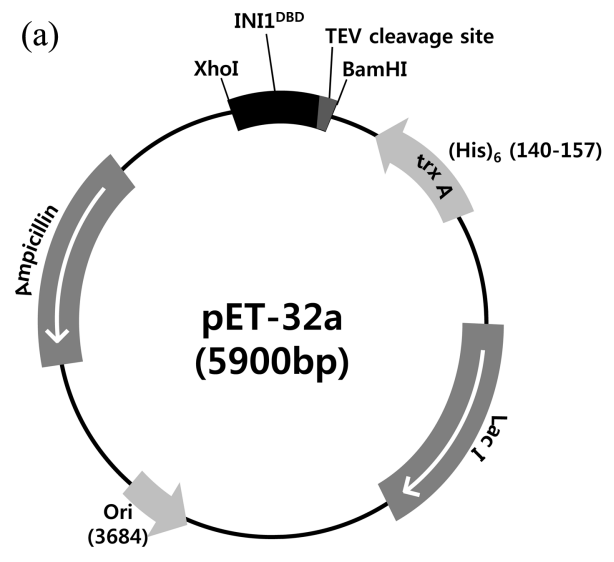

(b)

HIV-1

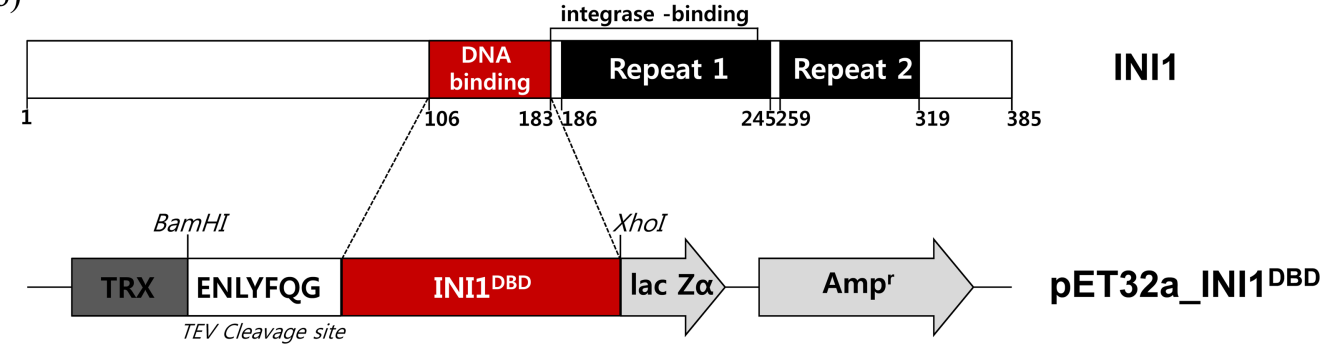

(c)

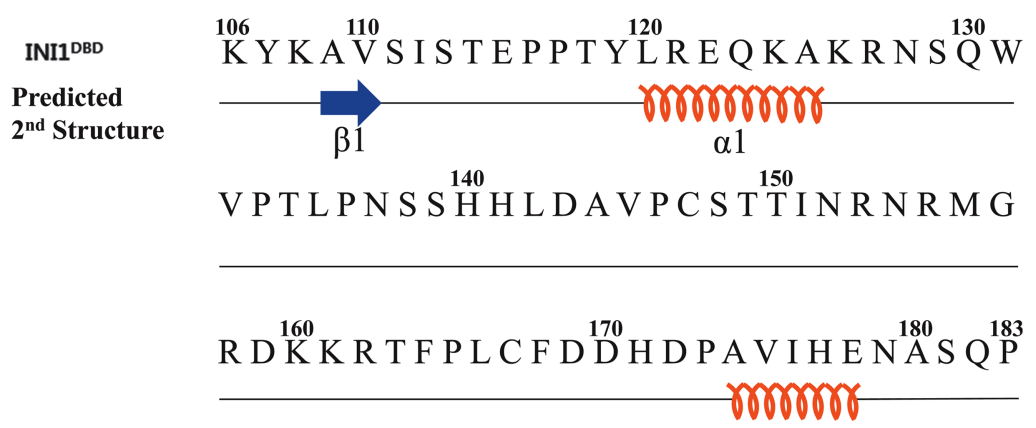

Figure 1. Schematic representation of the vector map and structural domains of INI1/hSNF5. (a) The vector map of INI $1^{\mathrm{DBD}}$ expressed in E. coli with TEV cleavage site is shown. (b) Structural domains of INI1/hSNF5 are drawn by data from previous studies. ${ }^{18}$ The vector consists of a Thioredoxin, (His) 6 tag and TEV enzyme cleavage site (ENLYFQG). (c) Secondary structures and primary sequence of INI $1^{\text {DBD }}$ were shown. Secondary structures were predicted by psi-pred server (http://bioinf.cs.ucl.ac.uk/psipred/). 
based on data from Morozov et al. ${ }^{18}$ and purified using polyacrylamide gel electrophoresis (PAGE) (Operon). Binding affinities between GAL4 DNA and INI1 ${ }^{\mathrm{DBD}}$ were measured on a model RF-5301PC spectro-fluorophotometer (Shimadzu, Kyoto, Japan). INI1 ${ }^{\text {DBD }}$ was titrated up to a molar ratio of 1:2.5 (INI1 ${ }^{\mathrm{DBD}}$ : GAL4 DNA) using a $2 \mathrm{~mL}$ thermostat cuvette. Samples were excited at $280 \mathrm{~nm}$ for sidechain of the aromatic residues of $\mathrm{INI} 1^{\mathrm{DBD}}$, and emission spectra were recorded for light scattering effects from 270 to $500 \mathrm{~nm} .{ }^{23}$ The $K_{d}$ values were calculated by the equation log $\left(\mathrm{F}_{0}-\mathrm{F} / \mathrm{F}\right)=\log \left(1 / \mathrm{K}_{\mathrm{d}}\right)+n \log$ [ligand], where $F_{0}$ and $F$ represent fluorescence intensity of the protein at $355 \mathrm{~nm}$ in the absence and presence of DNA ${ }^{24}$ respectively. The number $n$ represents the ligand binding site of the protein.

\section{Results and Discussion}

Cloning and Expression of INI1 ${ }^{\text {DBD }}$. DNA binding domain of INI1/hSNF5 corresponding residues from 106 to 183 was successfully cloned by PCR amplification and subcloned into pET32a (Novagen Inc.) at the BamHI and XhoI site (Fig. 1(a)). INI1/hSNF5 consists of three structural domains which are DNA binding, Repeats1 and Repeats2 domain (Fig. 1(b)). The construct contains TRX, hexahistidine $\left[(\mathrm{His})_{6}\right]$ affinity tag with TEV protease recognition sequence (ENLYFQG) in the N-terminus (Fig. 1(b)). INI1 ${ }^{\mathrm{DBD}}$
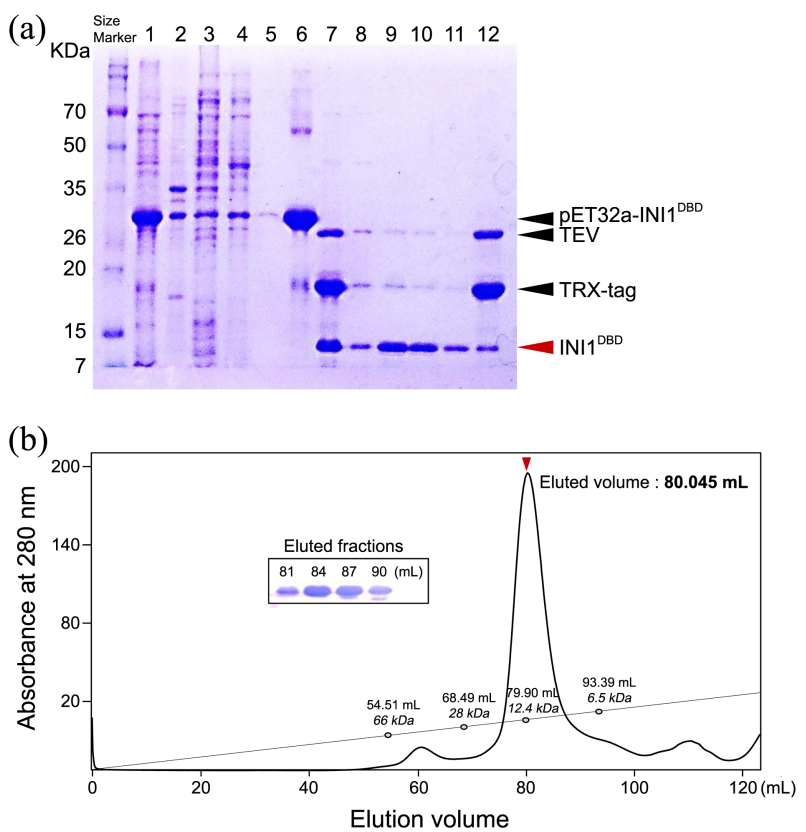

Figure 2. SDS page and elution profile of the size exclusion chromatography. (a) The SDS pages identify INI $1^{\mathrm{DBD}}$ during each purification steps. Lane 1 and 2 indicate supernatant and pellet of the cell lysate. Lane 3, 4 and 5 show the elution profiles, flowthrough, washing and elution, respectively. Lane 7, 8-11 and 12 indicate profile after tag cleavage, flow-through, washing and elution, respectively. (b) Elution profile of the size exclusion chromatography with SDS page. INI1 $1^{\mathrm{DBD}}$ was eluted from 80 to $90 \mathrm{~mL}$. Molecular weight of INI1 ${ }^{\mathrm{DBD}}$ was calculated by the equation, $\log \mathrm{Y}=-1.2177 \mathrm{X}+6.263\left(\mathrm{R}^{2}=0.9942, \mathrm{X}=\right.$ elution fraction $/ 45.85 \mathrm{~mL}$ ). protein was successfully expressed in both $250 \mathrm{~mL} \mathrm{LB}$ and M9 media using $1 \mathrm{mM} \mathrm{IPTG} \mathrm{at} 25^{\circ} \mathrm{C}$.

Purification of INI1 ${ }^{\text {DBD }}$. Data from Ni-NTA affinity chromatography shows that $\mathrm{INI} 1^{\mathrm{DBD}}$ is soluble in elution buffer. Fusion protein was eluted at imidazole concentration of $500 \mathrm{mM}$ and purified as a purity of $>90 \%$ as determined by sodium dodecyl sulfate-polyacrylamide gel electrophoresis (Fig. 2(a)). INI1 ${ }^{\mathrm{DBD}}$ was obtained after cleavage of Trx tag followed by Ni-NTA column work. Molecular weight of the purified fusion protein was determined as a $27 \mathrm{kDa}$ and $\mathrm{INI}^{\mathrm{DBD}}$ is $\sim 9 \mathrm{kDa}$ after cleavage of Trx tag. To increase protein purity and determine oligomeric state of $\mathrm{INI} 1^{\mathrm{DBD}}$, sizeexclusion chromatography was performed using HiLoad 16/ 60 superdex ${ }^{\mathrm{TM}} 75$. Data from size-exclusion chromatography shows that INI1 ${ }^{\mathrm{DBD}}$ forms a monomer $(\sim 9 \mathrm{kDa})$ in solution (Fig. 2(b)) by comparing reference proteins as a standard molecular marker. The final yields of the $\mathrm{INI}^{\mathrm{DBD}}$ protein are $10-15 \mathrm{mg}$ per $250 \mathrm{~mL}$ of cultured cell.

NMR Spectroscopy. One-dimensional NMR (1D-NMR) was used to confirm folded state of the purified INI ${ }^{\mathrm{DBD}}$. A number of high-field methyl proton resonances ranged from 0.5 to $1.0 \mathrm{ppm}$ as well as dispersion of amide proton resonances (7.5-9.5 ppm) strongly suggested that INI1 ${ }^{\mathrm{DBD}}$ has a stable folded structure under our experimental condition (Fig. 3(a)). $2 \mathrm{D}^{1} \mathrm{H}^{-15} \mathrm{~N}$ HSQC spectrum shows that most of

(a)

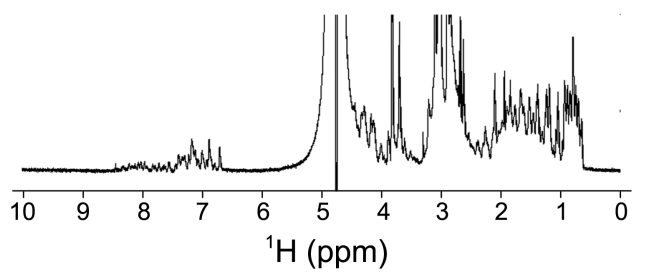

(b)

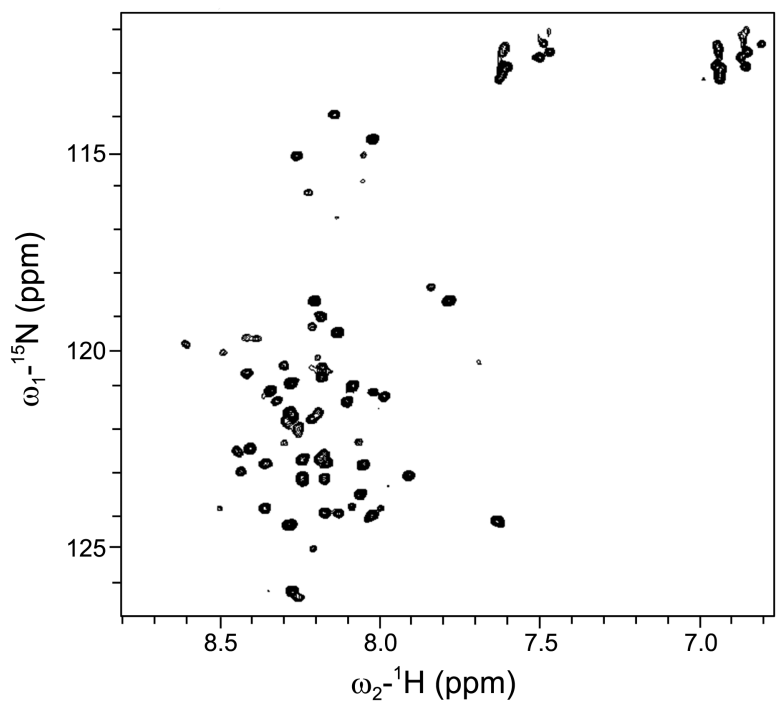

Figure 3. One-dimensional NMR and ${ }^{1} \mathrm{H}^{-15} \mathrm{~N} 2 \mathrm{D}$ HSQC spectra of INI ${ }^{\mathrm{DBD}}$. (A) One-dimensional ${ }^{1} \mathrm{H}$ NMR spectrum of INI1 ${ }^{\mathrm{DBD}}$ is shown. NMR sample was prepared in $10 \mathrm{mM}$ HEPES, $100 \mathrm{mM}$ $\mathrm{NaCl}, 2 \mathrm{mM}$ DTT, $0.01 \% \mathrm{NaN}_{3}$ solution, at $\mathrm{pH}$ 7.0. NMR experiment was performed on a Bruker DRX900 spectrometer. (b) ${ }^{1} \mathrm{H}-{ }^{15} \mathrm{~N} 2 \mathrm{D}$ HSQC spectrum was recorded using uniformly ${ }^{15} \mathrm{~N}$ labeled INI1 ${ }^{\mathrm{DBD}}$. 

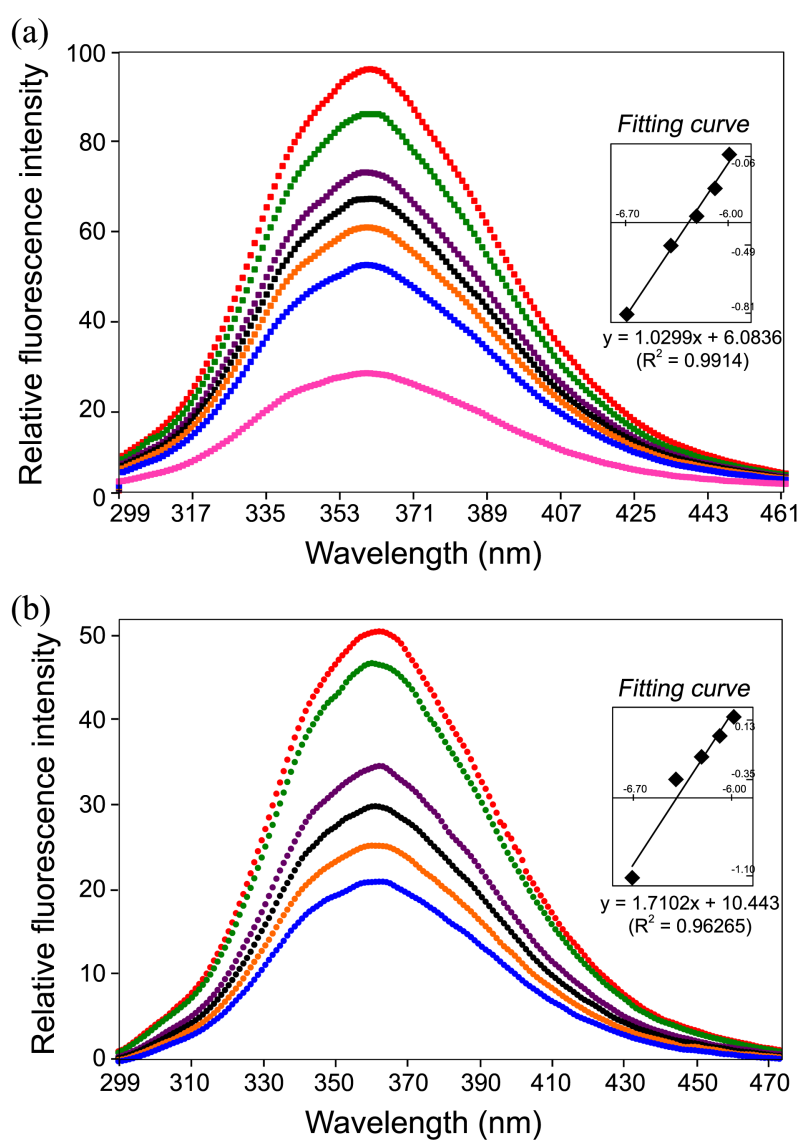

Figure 4. Fluoresence spectra of $\mathrm{INI} 1^{\mathrm{DBD}}$ in the presence of double-stranded DNA. (a) Fitting plot of INI $1^{\mathrm{DBD}}$ is shown in the presence of difference mixing ratio of double-stranded DNA (GAL4-1) (1:0 (red), 1:0.2 (green), 1:0.4 (purple), 1:0.6 (black), 1:0.8 (orange), 1:1 (blue), 1:2 (magenta)). (b) Fitting plot of INI1 ${ }^{\text {DBD }}$ with mixing ratio of double-stranded GAL4-2 DNA (1:0 (red), 1:0.2 (green), 1:1 (purple), 1:1.5 (black), 1:2 (orange), 1:2.5 (blue)).

backbone NH resonances were spread over the spectrum in NMR solution (10 mM HEPES, $100 \mathrm{mM} \mathrm{NaCl}, 2 \mathrm{mM}$ DTT and $0.01 \% \mathrm{NaN}_{3}$ at $\mathrm{pH} 7.0$ ) (Fig. 3(b)). Based on chemical shift information of the backbone amide proton and nitrogen resonances, we expect that $\mathrm{INI} 1^{\mathrm{DBD}}$ has high population of $\alpha$-helices.

DNA Binding of INI1 ${ }^{\text {DBD }}$. Previous report suggested that DNA binding domain of INI1/hSNF5 could interact with double strand DNA. ${ }^{18}$ Data from fluorescence-quenching experiments provide that the binding affinities between INI1 ${ }^{\text {DBD }}$ and two double stranded DNA fragments were determined as $29.9 \pm 2.6 \mu \mathrm{M}$ (GAL4 1) and $258.7 \pm 5.8$ (GAL4_2) $\mu \mathrm{M}$, respectively (Fig. 4(a)). The binding stoichiometry between the protein and DNA is calculated as 1:1 based on data from fluorescence spectroscopy. It is of interest to know that GAL4 1 binds 10 times stronger than GAL4_2. Taken together, these results revealed that DNA binding domain of INI1/hSNF5 binds to transcriptional DNA sequences, and INI1 ${ }^{\text {DBD }}$ could play an important role as a transcriptional regulator. Since it has also been suggested that INI1 ${ }^{\mathrm{DBD}}$ would mediate protein-protein interaction with HIV-1 integrase, ${ }^{7}$ INI1/hSNF5 could modulate viral replication of HIV-1 by binding to minor groove of DNA. This hypothesis will be revealed by structural information of INI1/HIV-1 integrase complex which is currently in progress.

\section{Conclusion}

DNA binding domain of INI1/hSNF5 is cloned into $E$. coli expression vectors, pET32a and purified using size exclusion chromatography. INI1 ${ }^{\mathrm{DBD}}$ was determined as a monomeric conformation in our experimental condition. Data from one-dimensional NMR and 2D ${ }^{1} \mathrm{H}_{-}{ }^{15} \mathrm{~N}$ HSQC show that INI1 ${ }^{\mathrm{DBD}}$ has folded state with high population of $\alpha$ helices. By fluorescence-quenching experiments, binding affinities between INI1 ${ }^{\mathrm{DBD}}$ and two double stranded DNA fragments were determined as $29.9 \pm 2.6 \mu \mathrm{M}$ (GAL4_1) and $258.7 \pm 5.8$ (GAL4_2) $\mu \mathrm{M}$, respectively, indicating $\overline{I N}^{\mathrm{N}} 1^{\mathrm{DBD}}$ could play an important role as a transcriptional regulator.

Acknowledgments. This work was supported by the Basic Science Research Program (NRF-2012R1A1A0242120) through the National Research Foundation of Korea (NRF) and by $900 \mathrm{MHz}$ NMR spectrometer at the Korea Basic Science Institute. This work is partially supported by Brain Korea plus $\left(\mathrm{BK}^{+}\right)$graduate student scholarship.

\section{References}

1. Kingston, R. E.; Bunker, C. A.; Imbalzano, A. N. Genes Dev. 1996, 10, 905-920.

2. Kingston, R. E.; Narlikar, G. J. Genes Dev. 1999, 13, 2339-2352.

3. Wang, W.; Cote, J.; Xue, Y.; Xhou, M.; Khavari, P. A.; Biggar, S. R.; Muchardt, C.; Kalpana, G. V.; Goff, S. P. \& other authors. EMBO J. 1996, 15, 5370-5382.

4. Wang, W.; Xue, Y.; Zhou, S.; Kuo, A.; Cairns, B. R.; Crabtree, G. R. Gens Dev. 1996, 10, 2117-2130.

5. Sudarsanam, P.; Lyser, V. R.; Brown, P. O.; Winston, F. PNAS. 2000, 97, 3364-3369.

6. Underhill, C.; Qutob, M. S.; Yee, S. P.; Torchia, J. J. Biol. Chem. 2000, 275, 40463-40470.

7. Kalpana, G. V.; Marmon, S.; Crabtree, G. R.; Goff, S. P. Science 1994, 266, 2002-2006.

8. Lee, D.; Kim, J. W.; See, T.; Hwang, S. G.; Choi, E. J.; Choe, J. J. Biol. Chem. 2002, 277, 22330-22337.

9. Hwang, S.; Lee, D.; Gwack, Y.; Min, H.; Choe, J. J. Gen. Virol. 2003, 84, 665-676.

10. Kwiatkowski, B.; Chen, S. Y.; Schubach, W. H. J. Virol. 2004, 78, 6067-6072.

11. Wu, D. Y.; Kalpana, G. V.; Goff, S. P.; Schubach, W. H. J. Virol. 1996, 70, 6020-6028.

12. Wu, D. Y.; Krumm, A.; Schubach, W. H. J. Virol. 2000, 74, 88938903.

13. Rozenblatt-Rogen, O.; Rozovskaiam, T.; Burakov, D.; Sedkov, Y.; Tillib, S.; Blechmanm, J.; Nakamura, T.; Croce, C. M.; Mazo, A.; Cannani, E. PNAS. 1998, 95, 4152-4157.

14. Alder, H. T.; Chinery, R.; Wu, D. Y.; Kussick, S. J.; Payne, J. M.; Fornace, A. J., Jr.; Tkachuk, D. C. Mol. Cell Biol. 1999, 19, 70507060 .

15. Lee, D.; Sohn, H.; Kalpana, G. V.; Choe, J. Nature 1999, 399, 487491 .

16. Imbazano, A. N.; Jones, S. N. Cancer Cell 2005, 7, 294-295.

17. Versteege, I.; Sevenet N.; Lange, J.; Rousseau-Merk, M. F.; 
Ambros, P.; Handgretinger, R.; Aurias, A.; Delattre, O. Nature 1998, 394, 203-206.

18. Morozov, A.; Yung, E.; Kalpana, G. V. PNAS. 1998, 95, 11201125 .

19. Singh, M.; D'Silva, L.; Holak. T. A. J. Biol. Chem. 2006, 387, $1469-1478$.

20. Yun, J.-H.; Kim, H.; Park, H. E.; Lee, J. S.; Lee, W. Bull. Korean Chem. Soc. 2012, 33, 3248.

21. Kay, L. E.; Keifer, P.; Saainen, T. J. Am. Chem. Soc. 2003, 114,
10663-10665

22. Delaglio, F.; Grzesiek, S.; Vuister, G. W.; Zhu, G.; Pfeifer, J.; Bax, A. J. Biomol. NMR 1995, 6, 277-293.

23. Barik, A.; Mishra, B.; Shen, L.; Mohan, H.; Kadam, R. M.; Dutta, S.; Zhang, H. Y.; Priyadarsini, K. I. Free Radic. Biol. Med. 2005, $39,811-822$.

24. Jiang, M.; Xie, M.; Zheng, D.; Liu, Y.; Li, X.; Chen, X. J. Mol. Struct. 2004, 692, 71-80. 